\title{
Uptake of L-nicotine and of 6-hydroxy-L-nicotine by Arthrobacter nicotinovorans and by Escherichia coli is mediated by facilitated diffusion and not by passive diffusion or active transport
}

\author{
Petra Ganas and Roderich Brandsch
}

Correspondence

Roderich Brandsch

roderich.brandsch@

biochemie.uni-freiburg.de

Received 25 February 2009

Revised 25 March 2009

Accepted 27 March 2009

\author{
Institut für Biochemie und Molekularbiologie, ZBMZ, Universität Freiburg, Stefan-Meier-Str. 17, \\ D-79104 Freiburg, Germany
}

\begin{abstract}
The mechanism by which L-nicotine is taken up by bacteria that are able to grow on it is unknown. Nicotine degradation by Arthrobacter nicotinovorans, a Gram-positive soil bacterium, is linked to the presence of the catabolic megaplasmid pAO1. L- $\left[{ }^{14} \mathrm{C}\right]$ Nicotine uptake assays with $A$.

nicotinovorans showed transport of nicotine across the cell membrane to be energy-independent and saturable with a $K_{\mathrm{m}}$ of $6.2 \pm 0.1 \mu \mathrm{M}$ and a $V_{\max }$ of $0.70 \pm 0.08 \mu \mathrm{mol} \mathrm{m^{-1 }}$ (mg protein) ${ }^{-1}$. This is in accord with a mechanism of facilitated diffusion, driven by the nicotine concentration gradient. Nicotine uptake was coupled to its intracellular degradation, and an $A$. nicotinovorans strain unable to degrade nicotine $\left(\mathrm{pAO}^{-}\right)$showed no nicotine import. However, when the nicotine dehydrogenase genes were expressed in this strain, import of $\mathrm{L}-\left[{ }^{14} \mathrm{C}\right]$ nicotine took place. A. nicotinovorans $\mathrm{pAO}^{-}$and Escherichia coli were also unable to import 6-hydroxy-L-nicotine, but expression of the 6-hydroxy-L-nicotine oxidase gene allowed both bacteria to take up this compound. L-Nicotine uptake was inhibited by D-nicotine, 6-hydroxy-L-nicotine and 2-amino-Lnicotine, which may indicate transport of these nicotine derivatives by a common permease. Attempts to correlate nicotine uptake with pAO1 genes possessing similarity to amino acid transporters failed. In contrast to the situation at the blood-brain barrier, nicotine transport across the cell membrane by these bacteria was not by passive diffusion or active transport but by facilitated diffusion.
\end{abstract}

\section{INTRODUCTION}

L-Nicotine (L-3-pyridyl- $N$-methylpyrrolidine), the main alkaloid synthesized by the tobacco plant, is an $N$ heterocyclic aromatic compound consisting of a pyridine and an $\mathrm{N}$-methylated pyrrolidine ring (see left insert of Fig. 1a). The pyrrolidine nitrogen confers the basic character to the molecule, with a $\mathrm{p} K_{\mathrm{a}}$ of 11 . Nicotine is an amphiphilic molecule soluble in organic media and in water. Nicotine consumption leads to addiction by stimulating nicotinergic acetylcholine receptors in the brains of smokers and by increasing dopamine release, which activates the selfreward system.

Nicotine inhaled with the tobacco smoke enters the bloodstream through the lung epithelium and can be located within seconds in the brain. Apparently, it easily crosses the blood-brain barrier without the help of any specific transport system (Crooks et al., 1997; Lockman

Abbreviations: DPI, diphenyleneiodonium; 6HLN, 6-hydroxy-L-nicotine; 6HLNO, 6-hydroxy-L-nicotine oxidase; 6HPON, 6-hydroxy-pseudooxynicotine; $\mathrm{NDH}$, nicotine dehydrogenase. et al., 2005). Accordingly, the only mechanism considered for nicotine uptake by mammalian tissues has been passive diffusion of the uncharged nicotine molecules (Schievelbein, 1982). This concept is supported by studies on $\mathrm{L}-\left[{ }^{14} \mathrm{C}\right]$ nicotine distribution in rat submaxillary gland slices (Putney \& Borzeleca, 1971). Nicotine uptake is apparently by passive diffusion only, shows no saturation kinetics and increases with an increase in extracellular $\mathrm{pH}$, which raises the fraction of uncharged nicotine molecules (Putney \& Borzeleca, 1971). In contrast, positively charged synthetic quaternary ammonium nicotine analogues, such as $N$-n-octylnicotinium iodide, apparently reach the brain by active transport via the blood-brain choline transporter (Allen et al., 2003).

Nicotine of decaying tobacco plants is degraded by soil micro-organisms, which can use this molecule as source of carbon, nitrogen and energy (Andreesen \& Fetzner, 2002; Brandsch, 2006). Metabolism of organic compounds by micro-organisms is initiated by their transport across the cell membrane. Aromatic lipophilic compounds may enter the bacterial cell by simple diffusion. In most cases, 
however, micro-organisms have evolved various uptake systems for compounds on which they can thrive. Uptake may be driven directly by ATP hydrolysis, or by secondary active transport, which takes advantage of an ion gradient across the membrane to transport in sym- or anti-port organic molecules into the cell. In this way, uptake can be achieved against the concentration gradient of the compound. Alternatively, uptake of nutrients may be achieved by facilitated diffusion along a concentration gradient with the aid of a permease (Saier, 2000). The transporters for many aromatic compounds have been shown to belong to the secondary active major facilitator superfamily of transporter proteins (Nichols \& Harwood, 1997; Prieto \& Garcia, 1997; Kahng et al., 2000; Kasai et al., 2001).

There is only limited information available on the uptake of nicotine from the environment by micro-organisms. In contrast to the situation at the blood-brain barrier, it seems not to penetrate the cell membrane of microbes by simple diffusion, and it has been suggested that nicotine uptake by Arthrobacter nicotinovorans is inducible. L$\left[{ }^{14} \mathrm{C}\right]$ Nicotine uptake assays show that only bacteria grown with nicotine are able to take up the alkaloid (Igloi \& Brandsch, 2003). In A. nicotinovorans the ability to use nicotine as a growth substrate has been linked to the presence of the $165 \mathrm{~kb}$ catabolic plasmid pAO1. An $A$. nicotinovorans strain without a functional pAO1 copy $\left(\mathrm{pAOl}^{-}\right)$or Escherichia coli, which cannot use nicotine for growth, show no import of nicotine (Igloi \& Brandsch, 2003).

In the present work we analysed L-nicotine and 6-hydroxyL-nicotine (6HLN) uptake by A. nicotinovorans and $E$. coli in greater detail, determined its energy requirements, the coupling of nicotine uptake to nicotine breakdown and its dependence on pAO1 genes.

\section{METHODS}

Chemicals. All chemicals used were of highest purity available. Diphenyleneiodonium (DPI), nigericin, valinomycin, monensin and PMSF were from Sigma-Aldrich. HEPES, MES, EDTA and DTT were from Carl Roth. L- $\left[{ }^{14} \mathrm{C}\right]$ Nicotine $\left(4.625 \times 10^{7} \mathrm{~Bq} \mathrm{mmol}^{-1}\right)$ was a kind gift of Professor Dr Karl Decker, Albert-Ludwigs University, Freiburg.

Bacterial strains, plasmids and growth conditions. A. nicotinovorans carrying the catabolic plasmid $\mathrm{pAO} 1\left(\mathrm{pAO}^{+}\right)$and a derived A. nicotinovorans strain unable to degrade nicotine $\left(\mathrm{pAOl}^{-}\right)$were grown at $30{ }^{\circ} \mathrm{C}$ on citrate medium supplemented with mineral salt solution, as described elsewhere (Brühmüller et al., 1972, 1975). E. coli XL1-Blue or XL10-Gold, used as host for recombinant plasmids, was grown on LB (lysogeny broth) medium at $37^{\circ} \mathrm{C}$.

Transformation of A. nicotinovorans with plasmids by electroporation was performed as described by Gartemann \& Eichenlaub (2001). E. coli XL1-Blue was made transformation-competent with Roti Transform and transformed as recommended by the supplier (Carl Roth). E. coli XL10-Gold ultracompetent cells were purchased from Stratagene.
Cloning of the hypothetical permease genes on pART2. The permease genes (perm) were amplified by PCR with the aid of specific primer pairs ( 1 and 2, 3 and 4, and 5 and 6; Table 1) using whole $A$. nicotinovorans $\mathrm{pAO}^{+}$cells as template. The amplified DNA of perm 1, perm 2 and perm 3 was digested with the restriction endonucleases $X b a \mathrm{I}$ and $N s i \mathrm{I}, K p n \mathrm{I}$ and $X b a \mathrm{I}$, and SalI and $X b a \mathrm{I}$, respectively, and the DNA fragments were inserted into plasmid pART2 (Sandu $e t$ al., 2005) that had been digested with SpeI and PstI (which give cohesive ends compatible with DNA cut with $X b a \mathrm{I}$ and NsiI), KpnI and $X b a \mathrm{I}$, or SalI and XbaI, by ligation with the Fast-Link DNA Ligation kit as recommended by the supplier (Epicentre Biotechnologies, Biozym Scientific). The 6hlno gene was amplified with the primer pair 7 and 8 (Table 1), digested with $X b a \mathrm{I}$ and ligated into pART2perm 1 cut with $X b a \mathrm{I}$ in such a way as to allow expression of both genes. The ligated plasmid DNA was transformed into E. coli XL10-Gold ultracompetent cells. Transformants carrying recombinant DNA were picked, and plasmid DNA isolated according to standard methods (QIAprep Spin Miniprep kit, Qiagen). The isolated pART2 DNA carrying the permease genes 1-3 was then electroporated into A. nicotinovorans $\mathrm{pAOl}^{-}$and transformants were grown on citrate medium in the presence of $140 \mu \mathrm{g}$ kanamycin $\mathrm{ml}^{-1}$.

Inactivation of permease genes by insertion of a chlor-

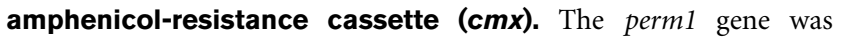
amplified with the aid of specific primers 9 and 10 (Table 1), and the PCR product was digested with BamHI and HindIII and ligated into pET21b cut with the same restriction endonucleases. The BamHI site of the multiple cloning site of pET21bperm 1 was deleted by digestion with $N h e$ I and religation. The $\mathrm{cm} x$ cassette was isolated from pOKU9, a derivative of pKGT452C $\beta$ (Gartemann \& Eichenlaub, 2001), by digestion with BamHI and ligated into the single BamHI site of the perm 1 gene. The perm 2 gene was amplified with primers 11 and 12 (Table 1), cut with the restriction endonucleases EcoRI and XhoI, and ligated into pMPM-A4 (Mayer, 1995) digested with the same enzymes. The chloramphenicol-resistance cassette of pKGT452C $\beta$ (Gartemann \& Eichenlaub, 2001) was amplified with specific primers 13 and 14 (Table 1), and inserted into perm2 (cut with $\mathrm{NcoI}$ and blunt-ended with the Klenow fragment of E. coli DNA polymerase I), carried on pMPM-A4. perm3 was amplified with primers 15 and 16 (Table 1), digested with HindIII and XhoI, and ligated into pH6EX3 (Berthold et al., 1992). The $c m x$ cassette isolated from pOKU9 by digestion with BamHI and blunt-ended by treatment with the Klenow fragment of DNA polymerase I was inserted into the PmlI site of perm3. The plasmids pET21b, pMPM-A4 and pH6EX3 are unable to replicate in $A$. nicotinovorans. The recombinant plasmids were transformed into E. coli XL1-Blue competent cells, and recombinant plasmid DNA was isolated from transformants selected on ampicillin plates and introduced by electroporation into A. nicotinovorans $\mathrm{pAO} 1^{+}$. The electroporated cells were spread on plates containing $15 \mu \mathrm{g}$ chloramphenicol $\mathrm{ml}^{-1}$. Resistant colonies were picked and grown on citrate medium in the presence of chloramphenicol, and the insertion of the $\operatorname{cm} x$ cassette into the permease gene was verified by PCR with permease-specific primers (27 and 28, 29 and 30, and 31 and 32; Table 1). Colonies with permease genes interrupted by the $\operatorname{cm} x$ cassette were picked and tested for nicotine uptake.

Construction of a recombinant pART2 plasmid carrying the ndhMSLcoxFmobA pA01 genes. The coxFmobA genes were amplified from A. nicotinovorans cells as a template (Table 1, primers 17 and 18), and the PCR product was digested with SalI and PstI and ligated into pUCBM20 (Yanisch-Perron et al., 1985) cut with the same enzymes. The $n d h M S L$ genes were also amplified with primers 19 and 20 (Table 1) and inserted into the EcoRI and HincII sites of pUCBM20 coxFmobA. The resulting recombinant plasmid pUCBM20ndhMSLCoxFmobA was used as a template for the PCR 
Table 1. Oligonucleotide primers used in this study

F, forward; R, reverse.

\begin{tabular}{|c|c|c|c|}
\hline Primer & Orientation & Sequence $\left(5^{\prime}-3^{\prime}\right)$ & $\begin{array}{l}\text { Amplified DNA fragment } \\
\text { (fragment size, bp) }\end{array}$ \\
\hline \multicolumn{4}{|l|}{ Cloning } \\
\hline 1 & $\mathrm{~F}$ & CACCATCTGCTCTAGAAACCTCG & \\
\hline 2 & $\mathrm{R}$ & CCGAAGTTTCATGCATCTGTGCCGG & \multirow[t]{2}{*}{ perm1 (1533) } \\
\hline 3 & $\mathrm{~F}$ & CAGAAGGTGGTACCTATGTC & \\
\hline 4 & $\mathrm{R}$ & GTGCCTCTTGTCTAGAAGCAACTTTAG & \multirow[t]{2}{*}{ perm2 (1426) } \\
\hline 5 & $\mathrm{~F}$ & CACCTGAAAGGTCGACACCTTTGC & \\
\hline 6 & $\mathrm{R}$ & CATGCAATGCTCTAGAGGCGGAAATC & \multirow[t]{2}{*}{ perm3 (1479) } \\
\hline 7 & $\mathrm{~F}$ & AAGCGCCCGATCTAGATAGTTGAAAG & \\
\hline 8 & $\mathrm{R}$ & AAGTGAGTCTAGAGGTTTCTACG & \multirow[t]{2}{*}{ 6hlno (1333) } \\
\hline 9 & $\mathrm{~F}$ & GCATTGCAGGATCCTTCTTCTG & \\
\hline 10 & $\mathrm{R}$ & GACGGTTATCAAGCTTCCTCCTTATAAAG & \multirow[t]{2}{*}{ perm1 (1852) } \\
\hline 11 & $\mathrm{~F}$ & CATACAGAAGGAATTCCCTATGTCTG & \\
\hline 12 & $\mathrm{R}$ & CGTCTTTCTTCGCTCGAGACTATTGG & \multirow[t]{2}{*}{ perm2 (1460) } \\
\hline 13 & $\mathrm{~F}$ & CCTCAACACCGAGCATGCTAAAG & \\
\hline 14 & $\mathrm{R}$ & CCGGTAGCGGCATGCCCATTTC & \multirow[t]{2}{*}{$\operatorname{cm} x(1845)$} \\
\hline 15 & $\mathrm{~F}$ & CCGCTTAAGCTTCGTGGTC & \\
\hline 16 & $\mathrm{R}$ & ACCTGCGCCTCGAGTCCTA & \multirow[t]{2}{*}{ perm3 (1538) } \\
\hline 17 & $\mathrm{~F}$ & CCTAGCAGATCGGGTCGACCATGCGTGACGTTA & \\
\hline 18 & $\mathrm{R}$ & GCATCGTCCTGCAGGAGGCGATA & \multirow[t]{2}{*}{ coxFmobA (2149) } \\
\hline 19 & $\mathrm{~F}$ & GGAAGATGAAGGGAATTCGAGGGAGT & \\
\hline 20 & $\mathrm{R}$ & TTTTCCTTCTTTCAAGTTTCTAGCT & \multirow[t]{2}{*}{$n d h M S L(3885)$} \\
\hline 21 & $\mathrm{~F}$ & GATGAAACTACCTGCTATCAGATA & \\
\hline 22 & $\mathrm{R}$ & TCGCATGCCTCTAGAACGCGATACATC & \multirow[t]{2}{*}{ ndhMSLcoxFmobA (5988) } \\
\hline 23 & $\mathrm{~F}$ & CTTGAAAGAAGGACGTCTTTGTATGAC & \\
\hline 24 & $\mathrm{R}$ & AAGTGAGTCTAGAGGTTTCTACG & \multirow[t]{2}{*}{$6 h \operatorname{lno}(1315)$} \\
\hline 25 & $\mathrm{~F}$ & AAGAAGGAAAGCTTTGTATGACGCGA & \\
\hline 26 & $\mathrm{R}$ & GTCTGCAGGTACCTACGAATGCAG & $6 h \operatorname{lno}(1304)$ \\
\hline \multicolumn{4}{|c|}{ Verification of gene inactivation } \\
\hline 27 & $\mathrm{~F}$ & CGATCGGTTCGGCATACTTCATCG & perm1 (532) \\
\hline 28 & $\mathrm{R}$ & CAAATGAGGAAGTAAGGGATCAC & perm1: cmx (2014) \\
\hline 29 & $\mathrm{~F}$ & GCAGATCGGCCAAATTGTCACA & perm2 (230) \\
\hline 30 & $\mathrm{R}$ & TATCGGTACAAGTGCGTAGACC & perm2: cmx (2075) \\
\hline 31 & $\mathrm{~F}$ & CTCAAGATATAGCCCATGCAGATC & perm3 (472) \\
\hline 32 & $\mathrm{R}$ & GATACGTCCAATCCTCGATAGGCG & perm3: cmx (1954) \\
\hline
\end{tabular}

amplification with primers 21 and 22 (Table 1) of the $n d h M S L$ coxFmobA DNA, which was cloned, following digestion with $X b a \mathrm{I}$, into pART2 cut with DraI and XbaI. Expression of the genes was monitored by measuring the nicotine dehydrogenase (NDH) activity in the extracts of $A$. nicotinovorans $\mathrm{pAO}^{-}$transformed with the recombinant plasmid. In order to induce the synthesis of the molybdenum cofactor, the transformed strains were grown in the presence of $150 \mu \mathrm{M}$ xanthine.

Construction of recombinant PART2 and pH6EX3 carrying the 6hIno gene of pAO1. The 6hlno gene was amplified from pAO1 by PCR with primer pairs 23 and 24 and 25 and 26 (Table 1), and the amplified DNA was digested with the restriction enzymes AatII and $X b a \mathrm{I}$, or HindIII and KpnI, and inserted by ligation into the multiple cloning sites of pART2 and pH6EX3, respectively. The ligated recombinant plasmid DNA was transformed into E. coli XL10-Gold competent cells. pART26hlno plasmid DNA was isolated from E. coli XL10-Gold bacteria and introduced by electroporation into $A$. nicotinovorans.
Preparation of $A$. nicotinovorans and $E$. coli membrane vesicles. Bacterial membrane vesicles were prepared as described in Moser et al. (2007), with slight modifications. Briefly, A. nicotinovorans was grown in 11 citrate medium to $\mathrm{OD}_{600} 0.6-0.7$, and the cells were collected by centrifugation, suspended in $50 \mathrm{mM}$ potassium phosphate buffer, $\mathrm{pH} 6.6$, recentrifuged and taken up in $20 \mathrm{ml}$ phosphate buffer. Lysozyme was added $\left(1.5 \mathrm{mg} \mathrm{ml}^{-1}\right.$ final concentration, corresponding to $7.6 \times 10^{4} \mathrm{U}$ ) and the bacterial suspension was incubated for $30 \mathrm{~min}$ at $30{ }^{\circ} \mathrm{C}$. Then, Benzonase Nuclease (375 units, Novagen) and PMSF $(0.5 \mathrm{mM})$ were added and the bacteria were broken by two passages in a French pressure cell at 1000 p.s.i. $(6900 \mathrm{kPa})$. The bacterial lysate was centrifuged at $5000 \mathrm{~g}$ for $25 \mathrm{~min}$, and the resultant supernatant was diluted with $20 \mathrm{ml}$ $50 \mathrm{mM}$ potassium phosphate buffer, $\mathrm{pH} 6.6$, and centrifuged at $150000 \mathrm{~g}$ for $2 \mathrm{~h}$ in the $45 \mathrm{Ti}$ rotor of a Beckman centrifuge. After centrifugation, the membrane pellet was taken up in $50 \mathrm{mM}$ HEPES, $\mathrm{pH} 7.5,250 \mathrm{mM}$ sucrose, $1 \mathrm{mM}$ EDTA, $1 \mathrm{mM}$ DTT and $0.5 \mathrm{mM}$ PMSF. Half volumes of $3 \mathrm{M}$ potassium acetate were added to the membrane suspension and incubated for $15 \mathrm{~min}$ on ice. 
The suspension was layered on a $750 \mathrm{mM}$ sucrose cushion and centrifuged at $200000 \mathrm{~g}$ for $1 \mathrm{~h}$ in a TLA55 Beckman centrifuge rotor. The membrane pellet was suspended in $50 \mathrm{mM}$ HEPES, $\mathrm{pH} 7.5$, $250 \mathrm{mM}$ sucrose, $1 \mathrm{mM}$ EDTA, $1 \mathrm{mM}$ DTT and $0.5 \mathrm{mM}$ PMSF; aliquots of $50 \mu \mathrm{l}$ were frozen in liquid nitrogen and stored until use.

$\mathbf{L}-\left[{ }^{14} \mathbf{C}\right]$ Nicotine uptake assays. A. nicotinovorans was grown overnight in $10 \mathrm{ml}$ citrate medium to stationary phase $\left(\mathrm{OD}_{600} 1.0\right)$. Then, $25 \mu \mathrm{L} \mathrm{L}-\left[{ }^{14} \mathrm{C}\right]$ nicotine $\left(4.625 \times 10^{7} \mathrm{~Bq} \mathrm{mmol}^{-1}\right)$ was added to $100 \mu \mathrm{M}$. Samples $(1.5 \mathrm{ml})$ were removed at different time points, and the bacteria were pelleted by centrifugation at $18000 \mathrm{~g}$ for $2 \mathrm{~min}$, resuspended in $1 \mathrm{ml}$ double-distilled water and repelleted. The washed bacteria were resuspended in $50 \mu \mathrm{l} 50 \mathrm{mM}$ Tris/ $\mathrm{HCl}$ (pH 8.0), $10 \mathrm{mM}$ EDTA, $1 \mathrm{mg}$ lysozyme $\mathrm{ml}^{-1}$, treated with $100 \mu \mathrm{l}$ $200 \mathrm{mM} \mathrm{NaOH} / 1 \%$ SDS (w/v), and neutralized with $75 \mu \mathrm{l} 2 \mathrm{M}$ Tris/ $\mathrm{HCl}(\mathrm{pH} 7.0) / 0.5 \mathrm{M} \mathrm{NaCl}$. The samples were centrifuged at $18000 \mathrm{~g}$ and the protein concentration in the supernatant was determined with Roti-Quant according to the instructions of the supplier (Roth). A $150 \mu \mathrm{l}$ volume of the cleared supernatant (18.5 $\mu \mathrm{g}$ protein) was added to $4.5 \mathrm{ml}$ scintillation solution (Roth), and the radioactivity was counted in a Packard liquid scintillation counter for $5 \mathrm{~min}$. The experiments were performed at least three times and the SD was calculated based on these datasets. Scintillation counting revealed that $<5 \%$ of the radioactivity was present in the pellets of the lysates.

Alternatively, the bacteria were grown overnight in $10 \mathrm{ml}$ citrate medium in the presence of $1.23 \mathrm{mM}$ unlabelled nicotine. The bacteria were pelleted by centrifugation at $3550 \mathrm{~g}$, washed twice with citrate medium, and resuspended in the same volume of citrate medium; L$\left[{ }^{14} \mathrm{C}\right]$ nicotine $\left(4.625 \times 10^{7} \mathrm{~Bq} \mathrm{mmol}^{-1}\right)$ was added to $100 \mu \mathrm{M}$, and the assays were performed as described above.

Membrane vesicles were tested for nicotine transport in assays containing $50 \mu \mathrm{g}$ membrane protein in the following buffers: $20 \mathrm{mM}$ MES/KOH, pH 6.0, $100 \mathrm{mM}$ potassium acetate, $10 \mathrm{mM} \mathrm{MgSO}_{4}$; $20 \mathrm{mM}$ MES/NaOH, pH $6.0,100 \mathrm{mM}$ sodium acetate, $10 \mathrm{mM}$ $\mathrm{MgSO}_{4} ; 50 \mathrm{mM}$ HEPES, pH 6.0, $10 \mathrm{mM} \mathrm{MgSO}_{4}$. L- $\left[{ }^{14} \mathrm{C}\right]$ Nicotine was added $(12.5 \mu \mathrm{M})$, mixed and incubated for $3 \mathrm{~min}$ at $30{ }^{\circ} \mathrm{C}$. The assays were centrifuged at $200000 \mathrm{~g}$ for $1 \mathrm{~h}$ in a TLA55 rotor, and the membrane pellet was suspended in $100 \mu \mathrm{l}$ distilled water and added to $4.5 \mathrm{ml}$ scintillation solution, and the radioactivity was counted in a Packard liquid scintillation counter for $5 \mathrm{~min}$.

Uptake of $6 \mathrm{HLN}$ by $A$. nicotinovorans $\mathrm{PAO1}^{-}$transformed with pART26hIno and $E$. coli transformed with pART26hlno or pH6EX36hIno. E. coli and A. nicotinovorans $\mathrm{pAOl}^{-}$carrying pART26hlno were grown overnight on LB and citrate medium, respectively. Non-transformed E. coli XL1-Blue and A. nicotinovorans $\mathrm{pAO1}^{-}$strains were employed as controls. The cells were harvested by centrifugation at $5000 \mathrm{~g}$ and suspended in $50 \mathrm{mM}$ potassium phosphate buffer, $\mathrm{pH}$ 7.1. An assay, dependent on the increase in $A_{334}$ on conversion by 6-hydroxy-L-nicotine oxidase (6HLNO) of $6 \mathrm{HLN}$ to 6-hydroxy-pseudooxynicotine $(6 \mathrm{HPON})\left(\varepsilon=20.7 \mathrm{mM}^{-1}\right.$ $\mathrm{cm}^{-1}$ at alkaline $\mathrm{pH}$ ) was performed in a $1 \mathrm{ml}$ volume. A $10 \mu \mathrm{l}$ volume of cell suspension of $A$. nicotinovorans $\mathrm{pAO}^{-}$carrying pART26hlno, $50 \mu \mathrm{l}$ of cell suspension of E. coli pART26hlno or $5 \mu \mathrm{l}$ of cell suspension of E. coli pH6EX36hlno was added to $50 \mathrm{mM}$ potassium phosphate buffer, $\mathrm{pH} 7.1$, containing $500 \mu \mathrm{M} 6 \mathrm{HLN}$. The assays were incubated for $10 \mathrm{~min}$ at $30^{\circ} \mathrm{C}$, the cells were removed by centrifugation, the supernatant was transferred into $1 \mathrm{ml}$ cuvettes and the absorption at $334 \mathrm{~nm}$ was measured in a UV/visible spectrophotometer (Amersham). The $\mathrm{pH}$ was adjusted to alkaline by adding $6 \mu \mathrm{l} 5 \mathrm{M} \mathrm{NaOH}$ solution and the difference in readings was recorded. Calculation of enzyme activity and product formation was standardized to $\mathrm{OD}_{600} 1$ in the assays.

To determine the effect of ionophores on 6HLN uptake into the cells, $5 \mu \mathrm{M}$ monensin, $10 \mu \mathrm{M}$ valinomycin or $2 \mu \mathrm{M}$ nigericin was added to

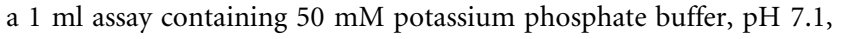
and a cell suspension of different bacterial strains. The assay was incubated for $5 \mathrm{~min}$ at room temperature before $500 \mu \mathrm{M}$ 6HLN was added. After incubation for $10 \mathrm{~min}$ at $30{ }^{\circ} \mathrm{C}$ the sample was processed following the protocol described above.

\section{RESULTS}

\section{Kinetics of nicotine uptake}

The time-course for $\mathrm{L}-\left[{ }^{14} \mathrm{C}\right]$ nicotine uptake (Fig. 1a, right insert) by $A$. nicotinovorans grown in citrate medium resulted in a bell-shaped curve (Fig. 1a). Nicotine uptake starts, as shown previously (Igloi \& Brandsch, 2003), with a lag-phase of approximately $10 \mathrm{~min}$, which coincided with the appearance of NDH and 6HLNO activity in the bacterial extracts. The bell-shaped curve resulted from the fact that methylamine produced from the pyrrolidine ring carrying the labelled methyl group (Chiribau et al., 2006) was extruded from the cells by the NepAB export pump (Ganas et al., 2007) (Fig. 1a, right insert TLC). After $2 \mathrm{~h}$ the culture medium started to turn blue, due to the secretion of nicotine blue, an end-product of nicotine catabolism (Brandsch, 2006). The A. nicotinovorans strain lacking a functional copy of pAO1 (A. nicotinovorans $\mathrm{pAO1}^{-}$) as well as E. coli showed no nicotine uptake (Fig. 1a). Nicotiana tabacum produces small amounts of the stereoisomer D-nicotine (Armstrong et al., 1999). D-Nicotine inhibited L- $\left[{ }^{14} \mathrm{C}\right]$ nicotine uptake, suggesting that the stereoisomers are transported by the same route (Fig. 1a).

When A. nicotinovorans grown in citrate medium in the presence of unlabelled nicotine was tested, uptake of L$\left[{ }^{14} \mathrm{C}\right]$ nicotine started immediately, providing evidence for a nicotine-inducible transport mechanism (Fig. 1b).

To investigate the concentration-dependent uptake of L$\left[{ }^{14} \mathrm{C}\right]$ nicotine by A. nicotinovorans, $\mathrm{pAO} 1^{+}$cells grown in citrate medium overnight were incubated for $60 \mathrm{~min}$ with $\mathrm{L}-\left[{ }^{14} \mathrm{C}\right]$ nicotine. As shown in Fig. $1(\mathrm{c})$, the nicotine uptake by these cells was saturable. A $K_{\mathrm{m}}$ of $6.2 \mu \mathrm{M} \pm 0.1$, in good agreement with previous results (Igloi \& Brandsch, 2003), and a $V_{\max }$ of $0.70 \pm 0.075 \mu \mathrm{mol} \mathrm{min}{ }^{-1}(\mathrm{mg} \text { protein })^{-1}$ were determined. In contrast, $A$. nicotinovorans $\mathrm{pAO}^{-}$ showed no nicotine uptake even at high nicotine concentrations (Fig. 1c). The slight increase in radioactivity in the samples can be explained by non-specific contamination at these high nicotine concentrations. Similarly, $E$. coli showed no nicotine uptake (results not shown). These results suggested that nicotine uptake by A. nicotinovorans is not by passive diffusion.

\section{Coupling of nicotine uptake and nicotine degradation}

Nicotine degradation starts with the hydroxylation of nicotine at $\mathrm{C} 6$ of the pyridine ring which is performed by the molybdenum cofactor (MoCo)-dependent $\mathrm{NDH}$. Replacement of molybdenum in the growth medium with 

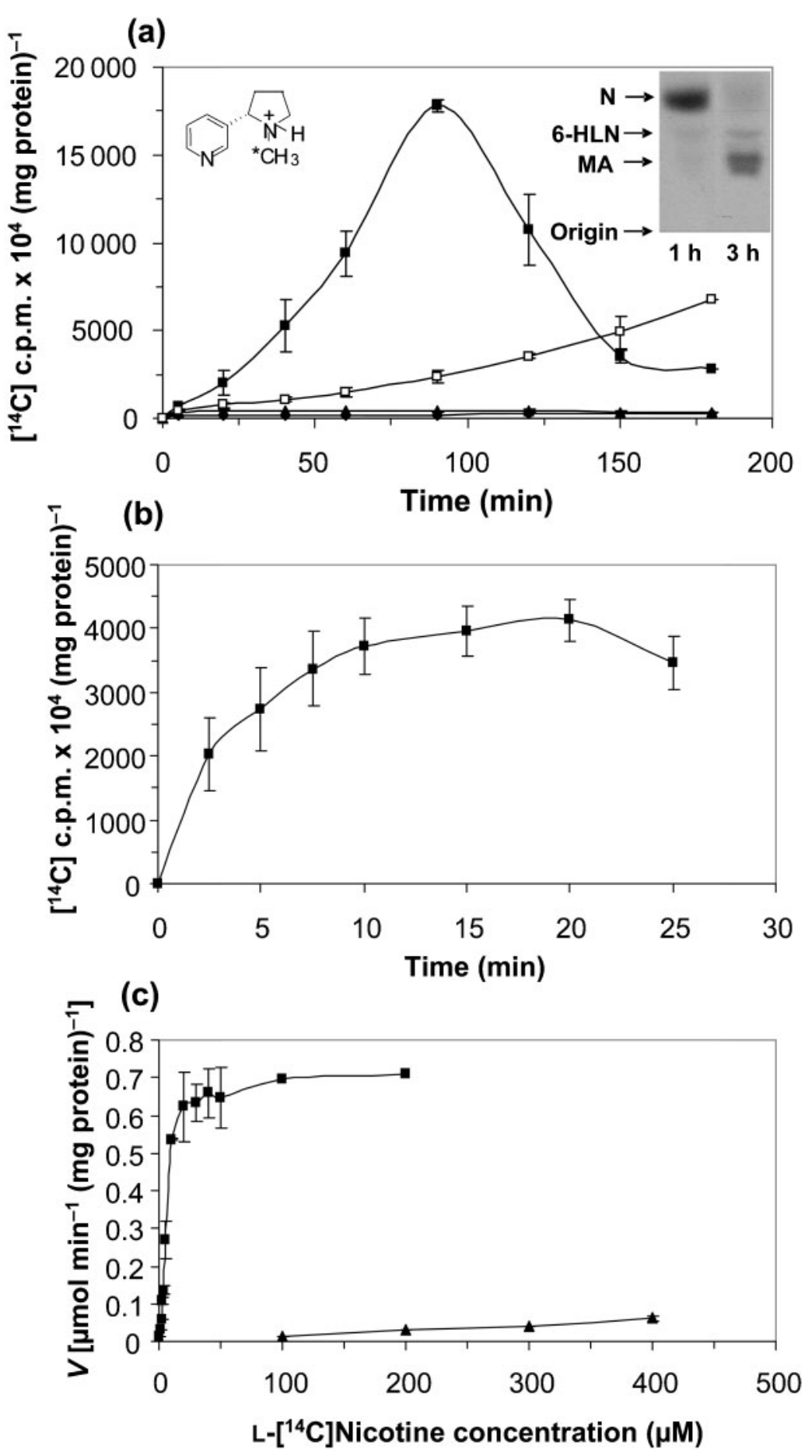

Fig. 1. Time-dependent and concentrationdependent nicotine uptake by bacterial strains. (a) A. nicotinovorans ( $\boldsymbol{\square})$, A. nicotinovorans $\mathrm{pAO}^{-}(\boldsymbol{\Delta})$ and $E$. coli XL1-Blue $(\boldsymbol{\Delta})$ bacteria grown overnight in citrate medium or LB medium in the absence of nicotine were incubated with $100 \mu \mathrm{M} \mathrm{L}-\left[{ }^{14} \mathrm{C}\right]$ nicotine, and time-dependent nicotine uptake was assayed as described in Methods. ( $\square$ ) L- $\left[{ }^{14} \mathrm{C}\right]$ Nicotine uptake by $A$. nicotinovorans in the presence of $1.5 \mathrm{mM}$ D-nicotine. Inserts: left, L- $\left[{ }^{14} \mathrm{C}\right]$ nicotine carrying the radioactive label at the $\mathrm{C}$ atom of the methyl group (indicated by an asterisk); right, TLC displaying the disappearance with time of $L-\left[{ }^{14} \mathrm{C}\right]$ nicotine $(\mathrm{N})$ from, and the appearance of $\left[{ }^{14} \mathrm{C}\right]$ methylamine $(\mathrm{MA})$ in, the growth medium. (b) Time-dependent uptake of $\mathrm{L}-\left[{ }^{14} \mathrm{C}\right]$ nicotine by $A$. nicotinovorans grown overnight in citrate medium in the presence of unlabelled nicotine. (c) Concentrationdependent kinetics of nicotine uptake by $A$. nicotinovorans ( $\boldsymbol{\square})$ and $A$. nicotinovorans $\mathrm{pAO}^{-}(\mathbf{A})$ grown overnight in citrate medium and then incubated with different concentrations of $L-\left[{ }^{14} \mathrm{C}\right]$ nicotine for $1 \mathrm{~h}$. tungsten leads to the formation of an inactive cofactor and inhibition of $\mathrm{NDH}$ activity (Grether-Beck et al., 1994; Baitsch et al., 2001). When L- $\left[{ }^{14} \mathrm{C}\right]$ nicotine uptake by bacteria grown in the presence of molybdenum was compared with uptake by bacteria grown in the presence of tungsten, it became apparent that uptake of nicotine was blocked in bacteria grown with tungsten (Fig. 2a). Control measurements of NDH activity in extracts of tungsten-grown bacteria confirmed the absence of enzyme activity (results not shown). However, when tungsten was added to L$\left[{ }^{14} \mathrm{C}\right]$ nicotine uptake assays performed with bacteria grown in the presence of molybdenum and unlabelled nicotine, tungsten did not inhibit $\mathrm{L}-\left[{ }^{14} \mathrm{C}\right]$ nicotine uptake (Fig. 2b). Apparently, active MoCo-containing $\mathrm{NDH}$ was present in these bacteria and tungsten no longer inhibited NDH activity and thus nicotine uptake. 

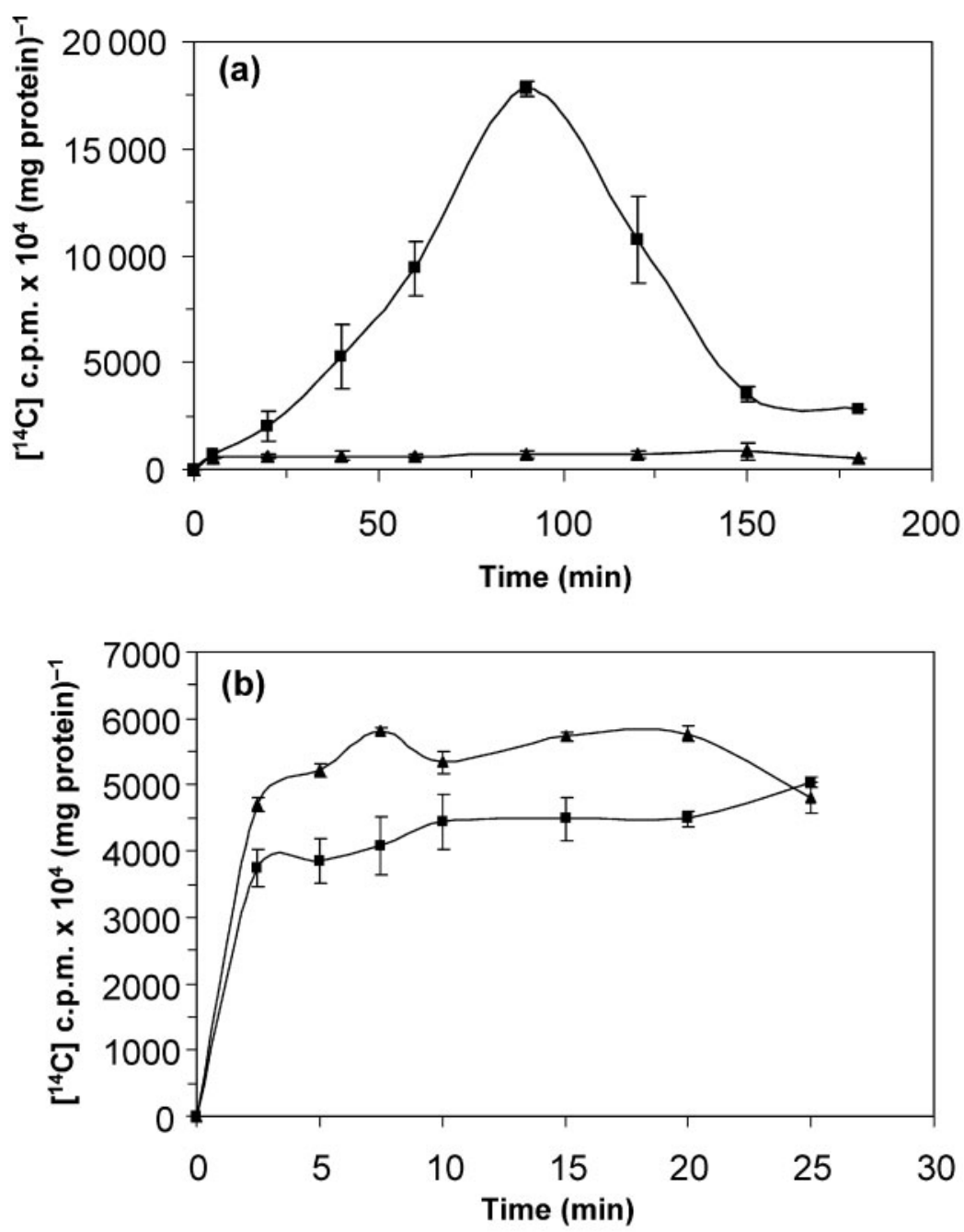

(c)

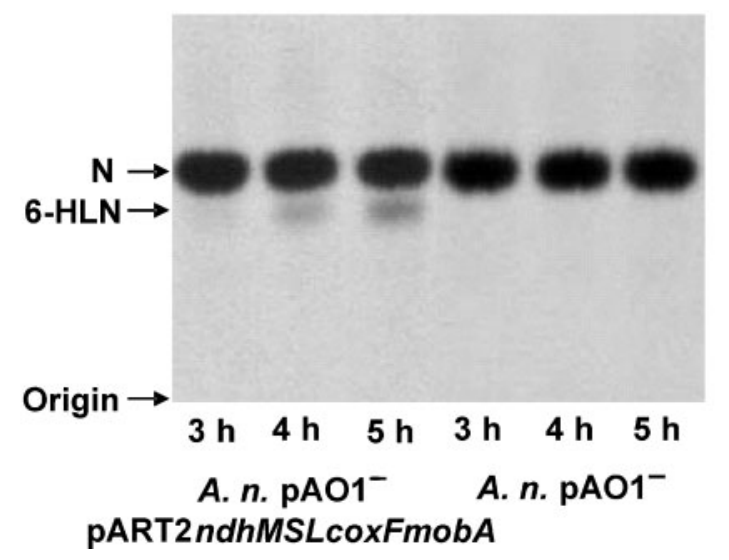

Fig. 2. Dependence of nicotine uptake on nicotine turnover. (a) $A$. nicotinovorans was grown overnight in citrate medium in the presence of molybdenum ( $\boldsymbol{\square}$ ) or tungsten $(\mathbf{\Delta})$, and time-dependent $\mathrm{L}-\left[{ }^{14} \mathrm{C}\right]$ nicotine uptake assays were performed with the bacteria as described in Methods. (b) $A$. nicotinovorans was grown in citrate medium overnight in the presence of nicotine and molybdenum, and time-dependent L$\left[{ }^{14} \mathrm{C}\right]$ nicotine uptake assays were performed with the washed bacteria in the absence ( $\boldsymbol{\square}$ ) and presence $(\boldsymbol{\Delta})$ of added tungsten. (c) $A$. nicotinovorans $\mathrm{pAO}^{-}$was transformed with the expression plasmid pART2 carrying the ndhMSLcoxFmobA genes and grown for $24 \mathrm{~h}$ at $30{ }^{\circ} \mathrm{C}$ in $100 \mathrm{ml}$ citrate medium supplemented with $150 \mu \mathrm{M}$ xanthine. The bacterial cells were centrifuged and resuspended in $1.5 \mathrm{ml} 100 \mathrm{mM}$ potassium phosphate buffer, $\mathrm{pH} 7.0$, in the presence of $200 \mu \mathrm{M} \mathrm{L-}$ $\left[{ }^{14} \mathrm{C}\right]$ nicotine, $200 \mu \mathrm{l}$ samples were taken from the assays at the time points indicated, centrifuged, and $7 \mu$ of the supernatant was applied to TLC plates (as described in Ganas et al., 2007). Control assays were performed with the untransformed $A$. nicotinovorans $\mathrm{pAO}^{-}$strain. The TLC plates were subjected to autoradiography and the films developed after 7 days of exposure.
When A. nicotinovorans $\mathrm{pAOl}^{-}$, which is unable to take up nicotine, was transformed with pART2 carrying the $n d h M S L$ and the coxFmobA genes, which are required for synthesis of molybdopterin cytosine dinucleotide (MCD) specific for NDH (Sachelaru et al., 2006), L- $\left[{ }^{14} \mathrm{C}\right]$ nicotine uptake became detectable by analysis of the growth medium (Fig. 2c). L- $\left[{ }^{14} \mathrm{C}\right]$ Nicotine taken up by the bacteria was converted into $\left[{ }^{14} \mathrm{C}\right] 6 \mathrm{HLN}$ by NDH, and in the absence of additional nicotine-degrading enzymes, $\left[{ }^{14} \mathrm{C}\right] 6 \mathrm{HLN}$ was released into the medium, where it was detected by TLC.

\section{Uptake of $6 \mathrm{HLN}$ by $A$. nicotinovorans $\mathrm{pAO1}^{-}$and $E$. coli expressing a functional $6 \mathrm{hlno}$ gene}

Taken together, the results presented above indicated that nicotine breakdown was a prerequisite for nicotine uptake. 
Since $6 \mathrm{HLN}$ and nicotine were apparently taken up by $A$. nicotinovorans by the same mechanism, we addressed the question of whether bacterial cells can be made competent for $6 \mathrm{HLN}$ uptake by expressing the 6hlno gene. The 6hlno gene was expressed in A. nicotinovorans and E. coli from the expression plasmids pART2 and pH6EX3. 6HLN was added to bacterial suspensions and the formation of $6 \mathrm{HPON}$ was assayed as described in Methods. As $6 \mathrm{HPON}$ is no longer degraded by the cells and is released into the culture medium, its presence can be measured by the increase in $A_{334}$ following a shift to $\geqslant \mathrm{pH}$ 9.5. In the absence of $6 \mathrm{HLN}$ uptake, its concentration in the assay should not change and no $6 \mathrm{HPON}$ should be formed. It was found that the expression of 6hlno conferred upon the bacterial strains the ability to take up 6HLN, as shown by the formation of $6 \mathrm{HPON}$ (Fig. 3a). The level of $6 \mathrm{HLNO}$ produced from the 6hlno gene under the control of the IPTG-inducible tac promoter of pH6EX3 in E. coli (1673 $\mathrm{mU} \mathrm{mg}^{-1}$ ) was higher than the level of $6 \mathrm{HLNO}$ produced from the constitutively expressed 6hlno gene
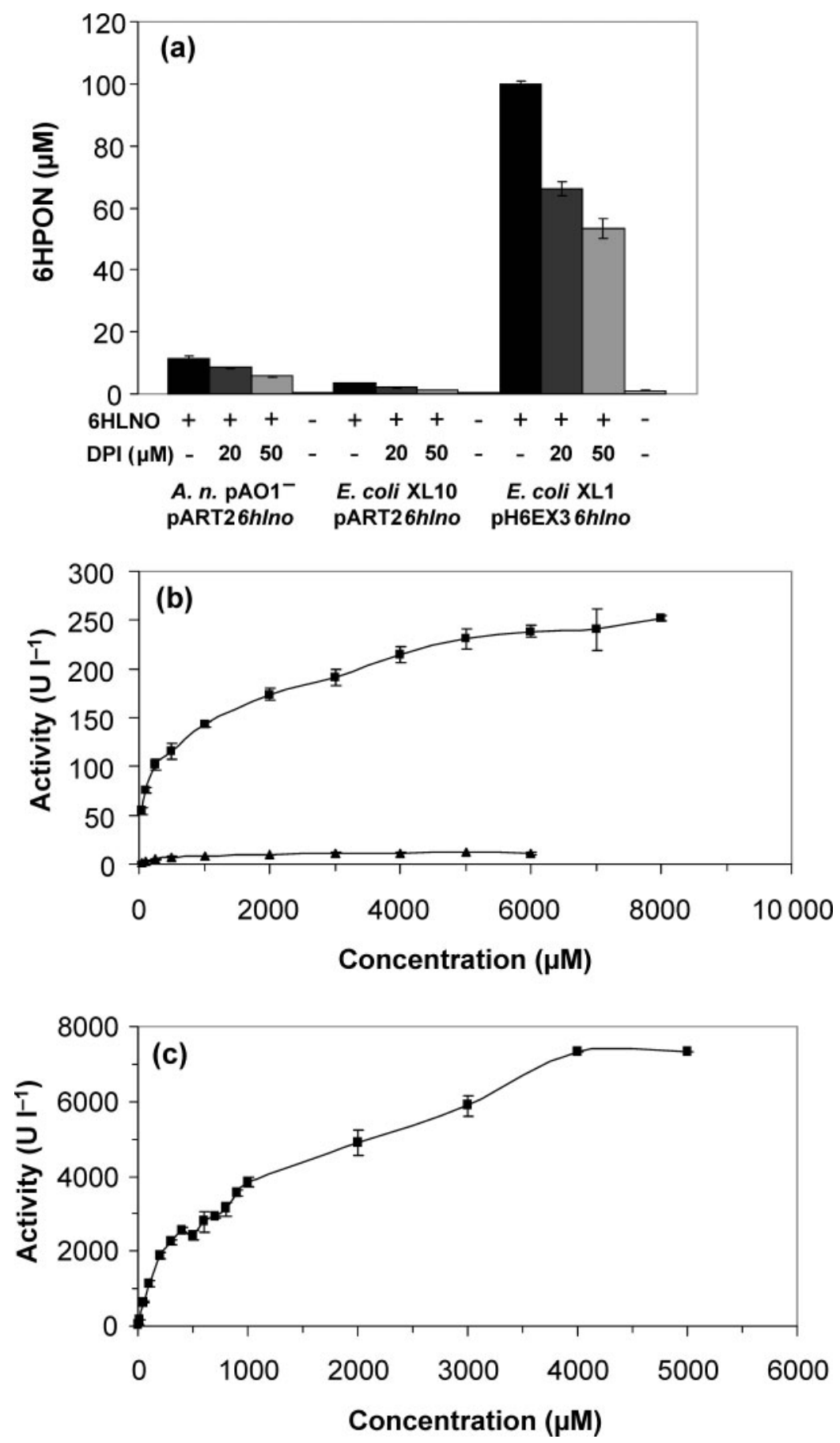

Fig. 3. Uptake of $6 \mathrm{HLN}$ by bacterial strains. $6 \mathrm{HLN}$ uptake assays were performed as described in Methods with A. nicotinovorans $\mathrm{pAO}^{-}$transformed with pART26hlno, or with untransformed controls and $E$. coli transformed with pART26hlno or pH6EX36hlno, or with untransformed controls $(\mathrm{a})$, in the presence of the additions indicated in the figure. (b) Saturation kinetics of $6 \mathrm{HLN}$ uptake by $A$. nicotinovorans $\mathrm{pAO}^{-}$carrying pART26hlno (ם) and by E. coli pART26hlno (A). (c) Saturation kinetics of $6 \mathrm{HLN}$ uptake by $E$. coli pH6EX36h/no. 
under the control of the 6hdno promoter of pART2 in A. nicotinovorans $\mathrm{pAO1}^{-}\left(31.29 \mathrm{mU} \mathrm{mg}^{-1}\right)$ and in E. coli (3.36 mU mg $\mathrm{m}^{-1}$ ). Addition of DPI, an inhibitor of flavoenzymes which penetrates bacterial cells (Brandsch \& Bichler, 1991), to the assays reduced the level of $6 \mathrm{HPON}$ in a concentration-dependent manner, an indication that $6 \mathrm{HLNO}$ activity was required for the production of $6 \mathrm{HPON}$ from externally added 6HLN (Fig. 3a). Uptake of $6 \mathrm{HLN}$ by $E$. coli and A. nicotinovorans $\mathrm{pAO1}^{-}$was saturable, consistent with transport of the molecule by facilitated diffusion (Fig. 3b, c).

As found for nicotine uptake (Ganas et al., 2007), dissipation of the $\mathrm{Na}^{+}, \mathrm{K}^{+}$and $\mathrm{H}^{+}$gradients by monensin, valinomycin and nigericin, respectively, did not significantly affect $6 \mathrm{HLN}$ uptake (results not shown).

\section{$L=\left[{ }^{14} C\right]$ Nicotine uptake assays with membrane vesicles}

If a permease for nicotine was expressed by A. nicotinovorans in response to nicotine in the growth medium, one might expect a higher number of permease molecules in the membranes of nicotine-grown bacteria than in membranes from bacteria grown in the absence of nicotine. When membrane preparations were incubated with $\mathrm{L}-\left[{ }^{14} \mathrm{C}\right]$ nicotine, no difference was found in nicotine content between membrane vesicles from bacteria grown in the presence and those grown in the absence of nicotine. The application of a $\mathrm{Na}^{+}$or $\mathrm{K}^{+}$gradient, or the absence of an ion gradient had no effect on the results. Membrane vesicles prepared from E. coli XL10-Gold showed the same level of radioactivity, which was considered to be background binding of L$\left[{ }^{14} \mathrm{C}\right]$ nicotine to membranes (results not shown). Apparently, no nicotine permease was present in the membrane preparations, or the absence of nicotine-degrading enzymes prevented nicotine uptake by the membrane vesicles.

\section{Specificity of nicotine uptake}

Assays were performed with A. nicotinovorans $\mathrm{pAO}^{+}$in the presence of compounds structurally related to nicotine, which might be expected to inhibit the uptake of $\mathrm{L}-$ $\left[{ }^{14} \mathrm{C}\right]$ nicotine if the transport involved a permease. Fig. 4 shows that the strongest inhibition of $\mathrm{L}-\left[{ }^{14} \mathrm{C}\right]$ nicotine uptake was observed with 2 -amino-L-nicotine, followed by $6 \mathrm{HLN}$, while 2,6-dihydroxypyridine had a slight effect, and 2,6-

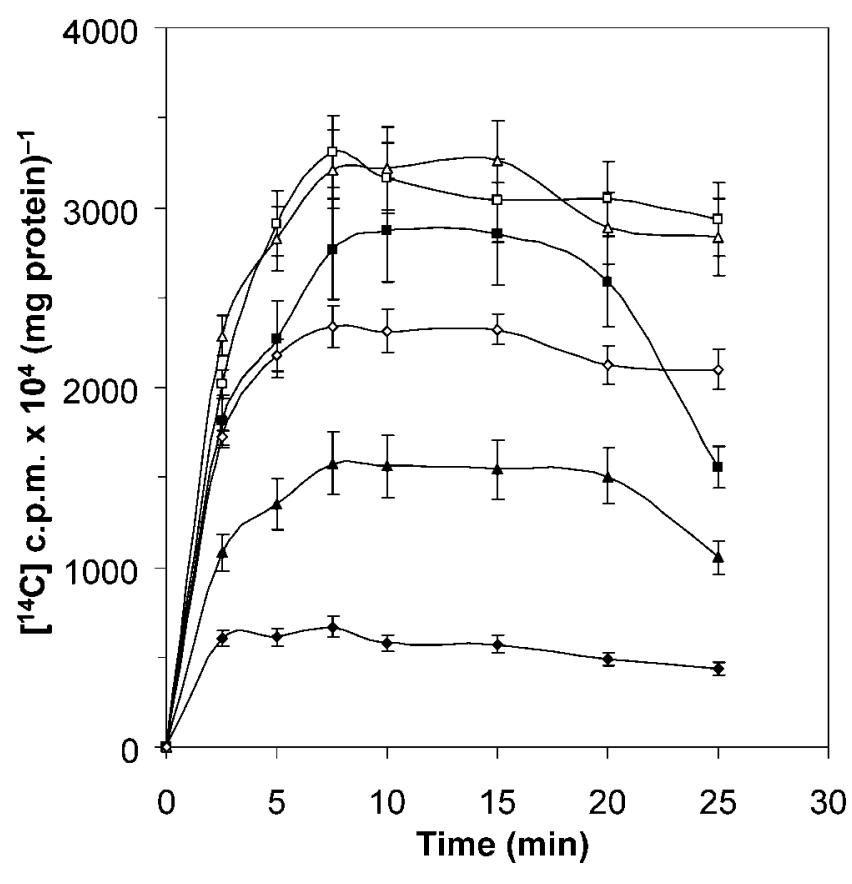

Fig. 4. Inhibition of $\mathrm{L}-\left[{ }^{14} \mathrm{C}\right]$ nicotine uptake by structurally related compounds. A. nicotinovorans was grown overnight in citrate medium in the presence of unlabelled nicotine, and the washed bacteria were used in nicotine uptake assays in the presence of various compounds which were added simultaneously with L$\left[{ }^{14} \mathrm{C}\right]$ nicotine. L- $\left[{ }^{14} \mathrm{C}\right]$ Nicotine uptake assay without additions (ש) and in the presence of $1 \mathrm{mM}$ of the following compounds: ( $\boldsymbol{\Delta})$ 6HLN, ( ()$_{)}$2-amino-L-nicotine, ( $\square$ ) 2,6-dihydroxynicotinic acid, $(\triangle)$ pyridine, $(\diamond)$ 2,6-dihydroxypyridine.

dihydroxynicotinamide and pyridine had no effect. Since positively charged synthetic quaternary ammonium nicotine analogues are actively transported across the blood-brain barrier by a choline transporter (Allen et al., 2003), we added choline or ethanolamine to the assays but observed no inhibition of nicotine uptake (results not shown).

\section{Attempts at identification of the nicotine permease(s)}

Within the nic- gene cluster of pAO1 there are three hypothetical genes that exhibit similarity to genes of amino acid transporters (Fig. 5) (Igloi \& Brandsch, 2003). Since
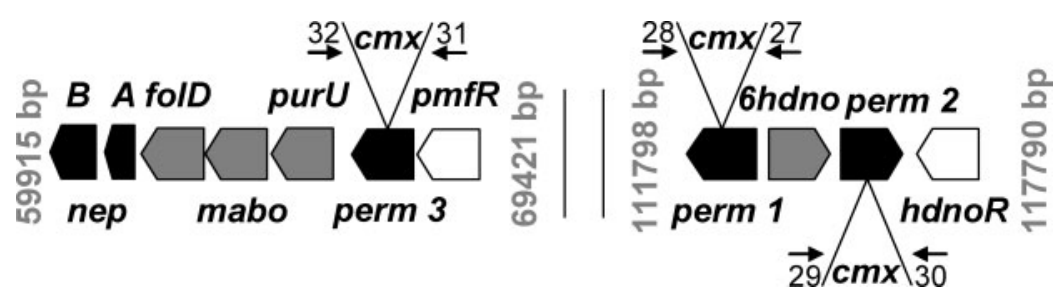

Fig. 5. pAO1 gene cluster with putative permease genes. Schematic representation of the position of the genes on pAO1 and inactivation of the permease genes by the insertion of a chloramphenicol-resistance cassette $(\mathrm{cm} x)$. Indicated are the PCR primers (see Table 1) used for verification of the insertion events. 

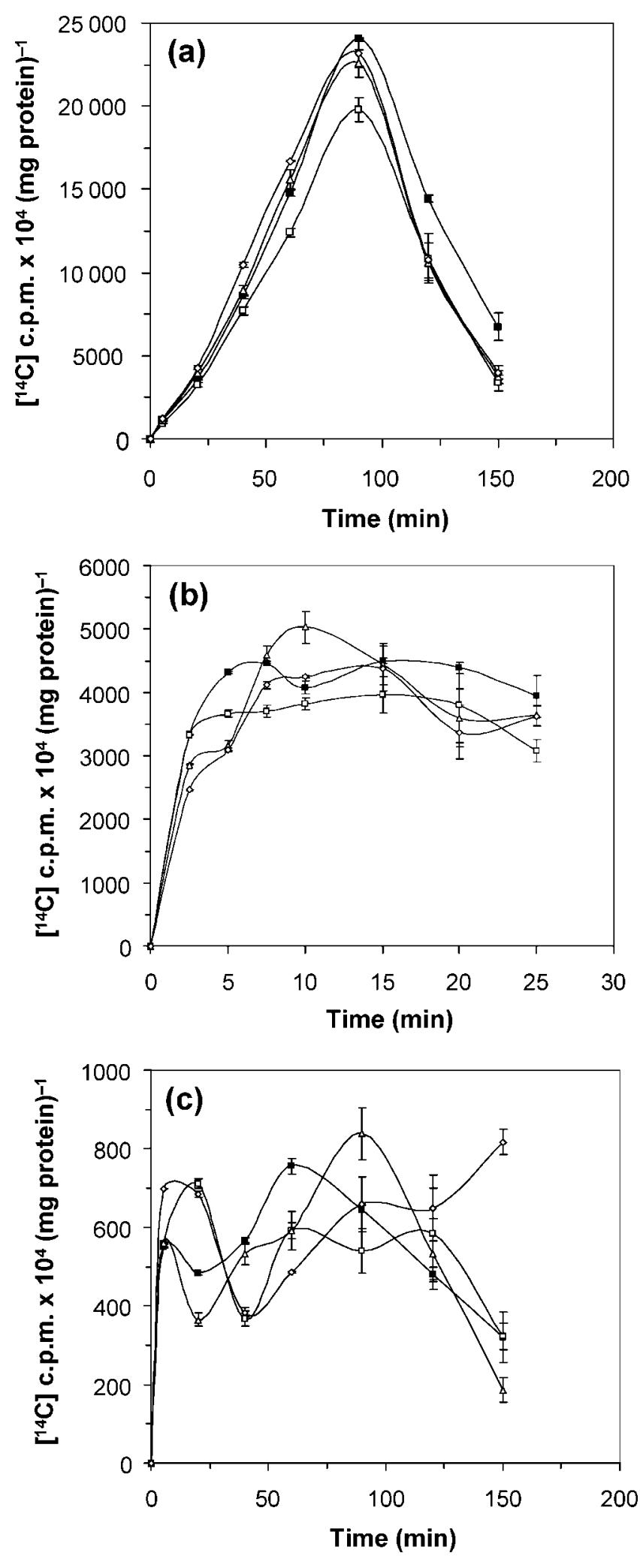

nicotine uptake has been shown to be influenced by the presence of amino acids in the medium (Igloi \& Brandsch, 2003), these predicted permeases were considered to be candidates for nicotine transporters. Expression of the
Fig. 6. $\mathrm{L}-\left[{ }^{14} \mathrm{C}\right]$ Nicotine uptake assays performed with $A$. nicotinovorans strains. Assays were performed with $A$. nicotinovorans ( $\boldsymbol{\square})$ and $A$. nicotinovorans carrying $\mathrm{cm} x$-inactivated perm $1(\square)$, perm2 $(\triangle)$ and perm3 $(\diamond)$ genes, grown overnight in the absence (a) or presence (b) of unlabelled nicotine. (c) L$\left[{ }^{14} \mathrm{C}\right]$ Nicotine uptake assays performed with $A$. nicotinovorans $\mathrm{pAO}^{-}(\boldsymbol{\square})$, and $A$. nicotinovorans $\mathrm{pAO}^{-}$transformed with pART2perm $1(\square)$, pART2perm2 $(\triangle)$ or pART2perm3 $(\diamond)$ grown overnight in citrate medium.

putative $\mathrm{pAO} 1$ permease genes has been shown previously to be dependent on the presence of nicotine in the growth medium (Sandu et al., 2003; Chiribau et al., 2004). If one of these genes encoded a nicotine permease, its inactivation should affect nicotine uptake by $A$. nicotinovorans. Therefore, inactivation of the individual permease genes was performed with the aid of a chloramphenicol-resistance cassette $(\mathrm{cm} x)$ that interrupted the respective ORF (Fig. 5). Insertion of the $\operatorname{cm} x$ cassette was verified by amplification with specific primers for the permease genes, as described in Methods, and the effect on nicotine uptake was tested. L- $\left[{ }^{14} \mathrm{C}\right]$ nicotine uptake by these strains was not significantly affected, irrespective of whether they were grown in the absence (Fig. 6a) or presence of unlabelled nicotine (Fig. 6b). The expression of the permease genes in A. nicotinovorans $\mathrm{pAO}^{-}$ when introduced on pART2 did not confer the ability to take up L- $\left[{ }^{14} \mathrm{C}\right]$ nicotine by these cells (Fig. 6c). Because nicotine transport is coupled to its breakdown, we transformed $E$. coli with pART2 carrying in addition to a permease gene the 6hlno gene (pART2perm16hlno). The transformed bacteria exhibited 6HLNO activity, but there was no increased 6HLN uptake detectable when compared with the strain expressing the 6hlno gene alone (results not shown).

\section{DISCUSSION}

What drives nicotine uptake into bacterial cells: is it by concentration-dependent facilitated diffusion or is it by primary or secondary active transport? It was known from previous studies that a proton-gradient-dependent small multidrug resistance pump, NepAB, was involved in the export of labelled breakdown products of nicotine (Ganas et al., 2007). Compounds that block ATP synthesis by dissipating the proton gradient [carbonylcyanide- $m$-chlorophenylhydrazone (CCCP) and 2,4-dinitrophenol (DNP)] and compounds that dissipate the $\mathrm{K}^{+}$(valinomycin), the $\mathrm{Na}^{+}$(monensin) or the $\mathrm{K}^{+}$and proton gradient (nigericin) across the cell membrane resulted in the inhibition of the NepAB export pump. In this situation, uptake of nicotine by the cells continued, leading to an increase in the level of intracellular radioactivity (Ganas et al., 2007). This conclusion was supported by the experiments presented in this work with regard to the energyindependent $6 \mathrm{HLN}$ uptake by A. nicotinovorans and E. coli expressing 6HLNO. These findings indicated that nicotine and $6 \mathrm{HLN}$ uptake was not driven by a primary or secondary active transport mechanism. Since nicotine 
uptake by A. nicotinovorans seemed to be neither by passive diffusion nor by energy-dependent transport, a mechanism of facilitated diffusion across the bacterial membrane appears to be active.

The delay in $\mathrm{L}-\left[{ }^{14} \mathrm{C}\right]$ nicotine uptake by A. nicotinovorans has been attributed to the need to induce the expression of nicotine transport and degradation genes (Igloi \& Brandsch, 2003). Since methylamine carrying the $\left[{ }^{14} \mathrm{C}\right]$ label is not further metabolized by A. nicotinovorans but secreted into the medium (Chiribau et al., 2006; Ganas et al., 2007) the time-dependent uptake of nicotine showed a bell shaped curve. L- $\left[{ }^{14} \mathrm{C}\right]$ nicotine could be taken up without delay by bacteria pre-grown in the presence of unlabelled nicotine, supporting a nicotine-inducible transport mechanism. The saturation kinetics for nicotine uptake pointed to a mechanism of facilitated diffusion by a permease, contrary to the suggested mechanism of passive diffusion of nicotine across the blood-brain barrier and rat submaxilary gland cells (Putney \& Borzeleca, 1971; Schievelbein, 1982; Lockman et al., 2005).

The presence of ORFs encoding putative amino acid permeases (Burkovski \& Krämer, 2002) within the nic gene cluster of pAO1 suggested a possible involvement of these gene products in nicotine transport. Such a gene arrangement is common in the organization of bacterial catabolic pathways (Nichols \& Harwood, 1997; Kahng et al., 2000; Rojas et al., 2001; Kasai et al., 2001; Hearn et al., 2003). Expression of these putative permease genes in the presence of nicotine in the growth medium pointed to their possible involvement in nicotine catabolism by A. nicotinovorans. However, all efforts to functionally link these permease genes to nicotine catabolism failed. The gene-inactivation experiments and the inability to induce nicotine uptake in $A$. nicotinovorans $\mathrm{pAO}^{-}$and in E. coli by expression of the perm genes, either alone or in combination with genes of nicotine-degrading enzymes, showed that these putative permeases were not the nicotine transporters. Additional support for the assumption that these permeases are not nicotine transporters is the fact that Nocardioides sp. JS614 harbours a nicotine catabolic pathway almost identical to that of A. nicotinovorans (Ganas et al., 2008), but lacks the permease genes found on $\mathrm{pAO}$. The physiological function of the hypothetical amino acid permeases in nicotine catabolism, if any, remains unclear.

Alternatively, a constitutively synthesized permease may fortuitously mediate nicotine transport. Since facilitated diffusion across the cell membrane by a permease is along the concentration gradient of the transported solute, a modification inside the cell of the imported molecule maintains the outside-inside gradient. Usually this is accomplished by the action of an enzyme that metabolizes the imported molecule. Indeed, nicotine transport was coupled to its intracellular breakdown. This was demonstrated by nicotine uptake following transformation and expression of the ndhMSL genes in A. nicotinovorans $\mathrm{pAO}^{-}$, a strain previously unable to do so. The coupling of nicotine uptake and nicotine breakdown may maintain the outside-inside nicotine gradient and thus facilitate its transport, similar to the mechanism of glucose uptake by the well-studied glucose transporters of mammalian cells (Mueckler, 1994). Also, 6HLN transport required the intracellular presence of $6 \mathrm{HLNO}$. As with nicotine, uptake of $6 \mathrm{HLN}$ was saturable and energy-independent in both $A$. nicotinovorans $\mathrm{pAOl}^{-}$and $E$. coli, in accord with a transport mechanism by facilitated diffusion. Higher 6HLNO activity correlated with increased 6HLN uptake, and inhibition of 6HLNO activity by the flavoenzyme inhibitor DPI (Brandsch \& Bichler, 1991) decreased 6HLN uptake. In the absence of 6HLNO from the bacteria, the $6 \mathrm{HLN}$ concentration in the assays did not change. Only in the presence of the enzyme did 6HPON appear in the cellfree supernatant of the import assays. These findings demonstrated that 6HLN entered the cells and was transformed by $6 \mathrm{HLNO}$ into $6 \mathrm{HPON}$, which, not being further metabolized, was released into the medium.

The incompatibility of the E. coli cofactor molybdopterin guanosine dinucleotide (MGD) with $\mathrm{NDH}$, which requires the molybdopterin cytosine dinucleotide (MCD) cofactor, prevented L- $\left[{ }^{14} \mathrm{C}\right]$ nicotine import assays with E. coli. Previous work (Roduit et al., 1997; Chiribau et al., 2006; Ganas et al., 2007) as well as this study show that when 6HLN accumulates inside bacterial cells during nicotine breakdown, it is released into the medium. The same occurred with $6 \mathrm{HPON}$, which accumulated in E. coli and A. nicotinovorans in the presence of 6HLNO.

6HLN accumulated inside the bacteria and was exported, presumably because of overloading of the degradation capacity of the pathway. Export of 6HLN from and import of $6 \mathrm{HLN}$ into the bacterial cells may take place along the concentration gradient of $6 \mathrm{HLN}$ by the same permease. From the experiments showing inhibition of nicotine uptake by structurally related compounds one may speculate that L-nicotine, D-nicotine, $6 \mathrm{HLN}$ and 2-aminoL-nicotine share the same permease. Both 6HLN and Dnicotine also induce expression of the nic genes of pAO1 (Gloger \& Decker, 1969; Schenk et al., 1998). The absence of the pyrrolidine ring in pyridine and hydroxypyridine renders these compounds inactive with respect to nicotine uptake. Apparently, the pyrrolidine ring of nicotine is one of the structural determinants recognized by the permease that facilitates nicotine transport. The nature of this permease, however, remains to be established.

\section{ACKNOWLEDGEMENTS}

We thank Dr Gabor L. Igloi, Universität Freiburg, for critically reading the manuscript. This work was supported by a grant of the Deutsche Forschungsgemeinschaft to R. B.

\section{REFERENCES}

Allen, D. D., Lockman, P. R., Roder, K. E., Dwoskin, L. P. \& Crooks, P. A. (2003). Active transport of high-affinity choline and nicotine 
analogs into the central nervous system by the blood-brain barrier choline transporter. J Pharmacol Exp Ther 304, 1268-1274.

Andreesen, J. R. \& Fetzner, S. (2002). The molybdenum-containing hydroxylases of nicotinate, isonicotinate, and nicotine. Met Ions Biol Syst 39, 405-430.

Armstrong, D. W., Wang, X., Lee, J.-T. \& Liu, Y.-S. (1999). Enantiomeric composition of nornicotine, anatabine, and anabasine in tobacco. Chirality 11, 82-84.

Baitsch, D., Sandu, C., Brandsch, R. \& Igloi, G. L. (2001). Gene cluster on pAO1 of Arthrobacter nicotinovorans involved in degradation of the plant alkaloid nicotine: cloning, purification, and characterization of 2,6-dihydroxypyridine 3-hydroxylase. J Bacteriol 183, 5262-5267.

Berthold, H., Scanarini, M., Abney, C. C., Frorath, B. \& Northemann, W. (1992). Purification of recombinant antigenic epitopes of the human $68-\mathrm{kDa}(\mathrm{U} 1)$ ribonucleoprotein antigen using the expression system pH6EX3 followed by metal chelating affinity chromatography. Protein Expr Purif 3, 50-56.

Brandsch, R. (2006). Microbiology and biochemistry of nicotine degradation. Appl Microbiol Biotechnol 69, 493-498.

Brandsch, R. \& Bichler, V. (1991). Autoflavinylation of apo6hydroxy-D-nicotine oxidase. J Biol Chem 266, 19056-19062.

Brühmüller, M., Möhler, H. \& Decker, K. (1972). Covalently bound flavin in D-6-hydroxynicotine oxidase from Arthrobacter oxidans. Purification and properties of D-6-hydroxynicotine oxidase. Eur J Biochem 29, 143-151.

Brühmüller, M., Schimz, A., Messmer, L. \& Decker, K. (1975). Covalently bound FAD in D-6-hydroxynicotine oxidase. Immunological studies of $\mathrm{D}$ - and L-6-hydroxynicotine oxidase: evidence for a D-enzyme precursor. J Biol Chem 250, 7747-7751.

Burkovski, A. \& Krämer, R. (2002). Bacterial amino acid transport proteins: occurence, functions, and significance for biotechnological applications. Appl Microbiol Biotechnol 58, 265-274.

Chiribau, C.-B., Sandu, C., Fraaije, M., Schiltz, E. \& Brandsch, R. (2004). A novel $\gamma$-N-methylaminobutyrate demethylating oxidase involved in catabolism of the tobacco alkaloid nicotine by Arthrobacter nicotinovorans pAO1. Eur J Biochem 271, 4677-4684.

Chiribau, C.-B., Mihasan, M., Ganas, P., Igloi, G. L., Artenie, V. \& Brandsch, R. (2006). Final steps in the catabolism of nicotine. Deamination versus demethylation of $\gamma$ - $N$-methylaminobutyrate. FEBS J 273, 1528-1536.

Crooks, P. A., Li, M. \& Dwoskin, L. P. (1997). Metabolites of nicotine in rat brain after peripheral nicotine administration. Drug Metab Dispos 25, 47-54.

Ganas, P., Mihasan, M., Igloi, G. L. \& Brandsch, R. (2007). A twocomponent small multidrug resistance pump functions as a metabolic valve during nicotine catabolism by Arthrobacter nicotinovorans. Microbiology 153, 1546-1555.

Ganas, P., Sachelaru, P., Mihasan, M., Igloi, G. L. \& Brandsch, R. (2008). Two closely related pathways of nicotine catabolism in Arthrobacter nicotinovorans and Nocardioides sp. strain JS614. Arch Microbiol 189, 511-517.

Gartemann, K. H. \& Eichenlaub, R. (2001). Isolation and characterization of IS1409, an insertion element of 4-chlorobenzoate-degrading Arthrobacter sp. strain TM1, and development of a system for transposon mutagenesis. J Bacteriol 183, 3729-3736.

Gloger, M. \& Decker, K. (1969). Zum Mechanismus der Induktion nicotinabbauender Enzyme in Arthrobacter oxydans. Z Naturforsch 24b, 1016-1025.

Grether-Beck, S., Igloi, G., Pust, S., Schilz, E., Decker, K. \& Brandsch, R. (1994). Structural analysis and molybdenum-dependent expression of the pAO1-encoded nicotine dehydrogenase genes of Arthrobacter nicotinovorans. Mol Microbiol 13, 929-936.

Hearn, E. M., Dennis, J. J., Gray, M. R. \& Foght, J. M. (2003). Identification and characterization of the emhABC efflux system for polycyclic aromatic hydrocarbons in Pseudomonas fluorescens cLP6a. J Bacteriol 185, 6233-6240.

Igloi, G. L. \& Brandsch, R. (2003). Sequence of the 165-kilobase catabolic plasmid pAO1 from Arthrobacter nicotinovorans and identification of a pAO1-dependent nicotine uptake system. J Bacteriol 185, 1976-1989.

Kahng, H.-Y., Byrne, A. M., Olsen, R. H. \& Kukor, J. J. (2000). Characterization and role of $t b u X$ in utilization of toluene by Ralstonia picketti PKO1. J Bacteriol 182, 1232-1242.

Kasai, Y., Inoue, J. \& Harayama, S. (2001). The Tol plasmid pWW0 $x y l N$ gene product from Pseudomonas putida is involved in $m$-xylene uptake. J Bacteriol 183, 6662-6666.

Lockman, P. R., McAfee, G., Geldenhuys, W. J., Van der Schyf, C. J., Abbruscato, T. J. \& Allen, D. D. (2005). Brain uptake kinetics of nicotine and cotinine after chronic nicotine exposure. J Pharmacol Exp Ther 314, 636-642.

Mayer, M. P. (1995). A new set of useful cloning and expression vectors derived from pBluescript. Gene 163, 41-46.

Moser, M., Panahandeh, S., Holzapfel, E. \& Müller, M. (2007). In vitro analysis of the bacterial twin-arginine-dependent protein export. Methods Mol Biol 390, 63-79.

Mueckler, M. (1994). Facilitative glucose transporters. Eur J Biochem 219, 713-725.

Nichols, N. N. \& Harwood, C. S. (1997). PcaK, a high-affinity permease for the aromatic compounds 4-hydroxybenzoate and protocatechuate from Pseudomonas putida. J Bacteriol 179, 50565061.

Prieto, M. A. \& Garcia, J. L. (1997). Identification of the 4hydroxyphenylacetate transport gene of Escherichia coli W: construction of a highly sensitive cellular biosensor. FEBS Lett 414, 293-297.

Putney, J. W. \& Borzeleca, J. F. (1971). On the mechanism of $\left[{ }^{14} \mathrm{C}\right]-\mathrm{L}-$ nicotine distribution in rat submaxillary gland in vitro. J Pharmacol Exp Ther 178, 180-191.

Roduit, J.-P., Wellig, A. \& Kiener, A. (1997). Renewable functionalized pyridines derived from microbial metabolites of the alkaloid $(S)$ nicotine. Heterocycles 45, 1687-1702.

Rojas, A., Duque, E., Mosqueda, G., Golden, G., Hurtado, A., Ramos, J. L. \& Segura, A. (2001). Three efflux pumps are required to provide efficient tolerance to toluene in Pseudomonas putida DOT-T1E. J Bacteriol 183, 3967-3973.

Sachelaru, P., Schiltz, E. \& Brandsch, R. (2006). A functional mobA gene for molybdopterin cytosine dinucleotide cofactor biosynthesis is required for activity and holoenzyme assembly of the heterotrimeric nicotine dehydrogenase of Arthrobacter nicotinovorans. Appl Environ Microbiol 72, 5126-5131.

Saier, M. H. (2000). A functional-phylogenetic classification system for transmembrane solute transporters. Microbiol Mol Biol Rev 64, 354-411.

Sandu, C., Chiribau, C.-B. \& Brandsch, R. (2003). Characterization of HdnoR, the transcriptional repressor of the 6-hydroxy-D-nicotine oxidase gene of Arthrobacter nicotinovorans pAO1, and its DNAbinding activity in response to $\mathrm{L}-$ and D-nicotine derivatives. $\mathrm{J}$ Biol Chem 278, 51307-51315.

Sandu, C., Chiribau, C.-B., Sachelaru, P. \& Brandsch, R. (2005). Plasmids for nicotine-dependent and independent gene expression in Arthrobacter nicotinovorans and other Arthrobacter species. Appl Environ Microbiol 71, 8920-8924. 
Schenk, S., Hoelz, A., Krauss, B. \& Decker, K. (1998). Gene structure and properties of enzymes of the plasmid-encoded nicotine catabolism of Arthrobacter nicotinovorans. J Mol Biol 284, 1323-1339.

Schievelbein, H. (1982). Nicotine, resorption and fate. Pharmacol Ther 18, 233-248.
Yanisch-Perron, C., Vieira, J. \& Messing, J. (1985). Improved M13 phage cloning vectors and host strains: nucleotide sequences of the M13mp18 and pUC19 vectors. Gene 33, 103-119.

Edited by: D. J. Arp 